\title{
Influencing Factors of Catering 020 Customer Experience: An Approach Integrating Big Data Analytics with Grounded Theory
}

\author{
Chunyang SHI, Yilei PEI*, Dandan LI, Ting WU
}

\begin{abstract}
In the era of digital economy, catering $\mathrm{O} 2 \mathrm{O}$ is developing rapidly. Catering $\mathrm{O} 2 \mathrm{O}$ (catering online to offline), namely catering takeout in the paper, means that customers place an order through online ordering platform, and delivery persons deliver the food provided by catering enterprises offline. Catering $02 \mathrm{O}$ conforms to the trend of the digital economy era, but exposes a variety of problems, such as lower feedback rate of the platform, lower timeliness of acceptance and handling, lower customer feedback satisfaction, and poorer customer experience. As China's leading e-commerce platform for life services, Meituan won the rating of not recommending to place an order in the report of "2020 China E-commerce User Experience and Complaint Monitoring". In order to improve customer experience and service satisfaction of catering $\mathrm{O} 2 \mathrm{O}$, this paper takes Meituan takeout as an example, integrates big data analytics and grounded theory to explore influencing factors of catering $\mathrm{O} 2 \mathrm{O}$ customer experience. With the big data analytics method, the main influencing factors are obtained from 54250 customer reviews, and then the grounded theory method is used to conduct indepth analysis on negative reviews, and influencing factors of $\mathrm{O} 2 \mathrm{O}$ customer experience are verified and confirmed. The results show that the main influencing factors of catering $\mathrm{O} 2 \mathrm{O}$ customer experience are catering food quality and delivery service quality and after-sale service quality. Catering food quality and delivery service quality have a significant impact on customer experience. Finally, from perspectives of catering $02 \mathrm{O}$ platforms and enterprises, the paper obtains management implications as follows: Catering 020 platforms should attach great importance on the service of contact points in distribution link, strengthen the last-mile delivery service quality, and improve the supervision and feedback mechanism; catering $\mathrm{O} 2 \mathrm{O}$ enterprises should ensure the quality, portion and package of catering food, so as to improve customer experience and win electronic word-of-mouth and customer satisfaction.
\end{abstract}

Keywords: big data analytics; customer experience; customer reviews; influencing factors; the grounded theory

\section{INTRODUCTION}

Under the impact of the Internet wave, catering $\mathrm{O} 2 \mathrm{O}$ in China is developing rapidly. At present, catering $\mathrm{O} 2 \mathrm{O}$ industry has become one of the industries with the highest degree of Internet in the local life service industry in China. According to the latest data of CCTV finance and economics, by the end of 2020, the total order volume of China's takeout had reached 17.12 billion, the year-on-year increase of $7.5 \%$, and the transaction scale of China's takeout market had reached RMB 835.2 billion, the yearon-year increase of $14.8 \%$. The number of takeout users in China is close to 500 million. Meituan as China's leading e-commerce platform for services, offers over 200 service categories, including catering, on-demand delivery, and other entertainment and lifestyle services, and covers 2800 cities and counties across China. The total annual numbers of transaction users and active online merchants of Meituan reached 480 million and 6.5 million at the end of September, 2020, respectively. According to China's Ecommerce user experience and complaint monitoring report in 2020 issued by $100 \mathrm{EC}$, Meituan ranks 19th in the consumption rating list of life service E-commerce in 2020 with a lower composite index less than 0.4 , and obtains the rating of not suggesting to place an order. Therefore, it is necessary to discuss and make the deep analysis of influencing factors of customer experience based on objective big data of catering $\mathrm{O} 2 \mathrm{O}$ takeout platform.

During the past decade, customer experience has enjoyed remarkable attention in both marketing research and practice. Customer experience and its influencing factors have been widely concerned by scholars and practitioners in a multitude of service industries, such as retailing (Grewal et al., 2009; Verhoef et al., 2009) [18, 51], hotel and accommodation (Xu and Chan, 2010) [56], restaurant (Ryu et al., 2012; Yrjölä, 2019) [43, 60], service design (Teixeira et al. 2012; Kumar et al., 2014; Lemon and Verhoef 2016; Bolton et al., 2018; Kranzbühler et al., 2018; Kuehnl et al., 2019), [8, 28-30, 34, 48], e-commerce
(Rose et al., 2012) [41] and online-to-offline (O2O) (Lemon and Verhoef, 2016; Bolton et al., 2018) [8, 34].

Existing researches emphasize influencing factors of customer experience, from perspectives of service encounters (Lemon and Verhoef, 2016; Hoffman \& Novak, 2017; Bolton et al., 2018; Kranzbühler et al., 2018; Kuehnl et al., 2019; Stein and Ramaseshan, 2020; Becker and Jaakkola 2020), [5, 8, 22, 28, 29, 34, 46], virtual environment (Bolton et al., 2014) [7], e-service innovation (Barrett et al., 2015; Larivière et al., 2017; Voorhees et al., 2017; Ciuchita, 2019) [4, 10, 32, 52], product perception (Rose et al., 2012) [41], and O2O (Cui and Zhu, 2014; Zhang and Zhao, 2014; Yu, 2015; Gao et al., 2015; Xu et al., 2015; Kong et al., 2017; Mao, 2018) [11, 13, 27, 36, $57,59,61]$.

Scholars find customers have been posting online reviews to praise or criticize their service experiences on the internet (González-Rodríguez et al., 2016; Kwok et al., 2017; Nieto-García et al., 2017) [16, 31, 38]. Quantitatively abundant and qualitatively authentic online reviews data are the precious source of information on customer experience. Notably, big data analyses based on online customer reviews have been more efficient than survey or interview studies in terms of sample size and timeliness (Escobar-Rodríguez et al., 2017; Garms, et al., 2017; Wellton et al., 2017) [12, 14, 55]. Moreover, the availability of big data analyzing tools, represented by Octopus Web Data Collector and Python program, has made it possible to identify and understand the core information in a piece of online customer review efficiently.

Based on the research gap of customer experience especially in China's catering $\mathrm{O} 2 \mathrm{O}$ context, as well as the latent business value hidden in the vast amount of online customer reviews readily accessible, this study aims at uncovering influencing factors of customer experience in catering $\mathrm{O} 2 \mathrm{O}$ in China by means of investigating their online reviews. More specifically, this study unfolds as follows. The literature review section provides a thorough retrospect of previous literatures regarding influencing 
factors of customer experience in catering $\mathrm{O} 2 \mathrm{O}$, big data analysis and the grounded theory, which forms the theoretical and methodological foundation of this study. The method section illustrates the technical detail of big data selection, acquisition, and text mining. The results section reports the statistical, semantical, and correlational facts, whereas the discussion section reciprocates with theoretical interpretation and managerial implication.

The theoretical significance of this study is embodied in the verification and extension of catering $\mathrm{O} 2 \mathrm{O}$ experience theory. Before this study, similar researches were conducted using either survey by questionnaire (Cui and $\mathrm{Zhu}, 2014$; $\mathrm{Xu}$ et al., 2015; Brocato et al., 2012; Ciuchita, 2019) [9-11, 57] or face-to-face semi-structured interview (Lemke et al., 2011; Aaltojarvi, Kontukoski \& Hopia, 2018) [1, 33], both of which rely heavily on researchers' a priori knowledge and are inevitably loaded with subjectivity. In another and different manner, this study obtains statistically big data generated in the real catering $\mathrm{O} 2 \mathrm{O}$ platform, and subsequently tests and justifies the theory in a complementally objective way. Besides, the explanation of findings from a data-driven perspective, also brings novel enrichment to the established catering $\mathrm{O} 2 \mathrm{O}$ experience theory.

The managerial significance of this study is manifested as the practical guidance for catering $\mathrm{O} 2 \mathrm{O}$ platform and enterprise operators, both within and outside China, to obtain critical information from authentic online review data and thereby purposefully enhance customer satisfaction and loyalty. The grounded theory-based online review analysis proposed in this study has proved to be a meaningful and cost-effective approach to probe and comprehend influencing factors of customer experience. More importantly, the approach is transferable from catering $\mathrm{O} 2 \mathrm{O}$ to other $\mathrm{O} 2 \mathrm{O}$ service industry to generate greater business insight.

\section{LITERATURE REVIEW}

\subsection{Customer Experience and its Influencing Factors}

Customer experience has been widely concerned by scholars. Some researchers delimit the scope of customer experience to a particular context, such as retail setting (Verhoefet al. 2009) [51], financial service setting (Klaus and Maklan, 2013) [26], service encounters (Kumar et al. 2014) [30]. Many scholars have the unique interpretation of customer experience. Klaus (2013) defines customer experience as "the customers' dynamic continuous evaluation process of their perceptions and responses to direct and indirect interactions with providers and their social environment pre-, during and post-purchase and/or consumption of the offering at any given point in time". [25] Based on this definition, customer experience is the result of the cognitive, affective, emotional, social, and physical responses a customer might have to elements that might or might not be controlled by a provider (Siqueira et al., 2019) [45]. Some scholars define customer experience from the perspective of service encounter, and consider customer experience as individual assessment, response, or reaction derived from the customer's interaction with any direct or indirect contact with a firm's physical environment, employees, other customers, core service, or other aspects related to service delivery (Grove and Fisk, 1992; Grace and O'Cass, 2004; Meyer and Schwager,
2007; Homburg et al., 2015; Lemon and Verhoef, 2016) $[17,19,23,34,37]$. Others define customer experience in the online context, and view customer experience as psychological state, perception, assessment, or subjective response derived from the customer's interaction with the online object, including functional, affective, and social attributes and responses, as well as a sense of flow (Novak et al., 2000; Rose et al., 2012) [39, 41]. Scholars have clearly defined online customer experience (OCE) as a "psychologically subjective response to the e-retail environment" and as "a complex, holistic, and subjective process resulting from interactions between consumers and the online environment" (Trevinal and Stenger, 2014) [49].

Regarding influencing factors of customer experience, researchers focus more from perspectives of product situation, such as category, package and logo design (Bolton et al., 2014) [7], quality and price. Some concentrate on service encounters (Lemon and Verhoef, 2016; Hoffman \& Novak, 2017; Bolton et al., 2018; Kranzbühler et al., 2018; Kuehnl et al., 2019; Stein and Ramaseshan, 2020; Becker and Jaakkola 2020) [5, 8, 22, 28, 29, 34, 46], such as service environment, service personnel, and core service. The results show that the realtime touch point evaluations significantly affect overall customer experience and that these effects significantly differ for utilitarian and hedonic motivation orientations (Stein and Ramaseshan, 2020) [46]. Some focus on the elements of virtual environment (Rose et al., 2012; Bolton et al., 2014) [7, 41], such as website layout, ease of use and privacy; Some concern e-service innovation (Barrett et al., 2015; Larivière et al., 2017; Voorhees et al., 2017; Ciuchita, 2019) [4, 10, 32, 52]. The introduction of incremental innovations in e-service is a critical service encounter initiated by the e-service provider that can affect customer experience (Larivière et al., 2017; Voorhees et al., 2017) [32, 52], and may enhance customer experience by improving how customers interact with the service through new designs and features (Barrett et al., 2015) [4]; The results also show that incremental changes in existing e-services affect the cumulative customer experience (Ciuchita, 2019) [10]. Izogo and Jayawardhena (2018) propose seven influencing factors of online shopping experience (OSE), namely, retail prices, complaint handling and product/service experience quality (Singh and Söderlund, 2019) [44], convenience, website functionality, relational experience and shopping enjoyment [24]. Others are more concerned with social factors, such as comments, word-of-mouth and reference group [14]. The study explores the factors influencing small business customer experience, special treatment benefits, social benefits and communication (Gilboa et al., 2019) [15].

In the restaurant context, scholars have identified a number of factors that influence customer experience. These include neat, prompt, and helpful service personnel (e.g., Andaleeb \& Conway, 2006; Ryu and Jang, 2008) [2, 42]; restaurant atmospherics, such as spatial layout, other guests (Andersson and Mossberg, 2004) [3], ambiance, aesthetics (Heung and $\mathrm{Gu}, 2012$ ) [21], ratings, location, reputation, and the convenience of parking; and foodrelated attributes, such as presentation, daily specials, the variety of the menu, or portion size and quantity (Harrington et al., 2012) [20]. Yrjölä (2019) introduces the 
customer value perspective to restaurant experience, and proposes its influencing factors including both customer value dimensions and traditional service product attributes [60].

Scholars have conducted extensive and in-depth research on customer experience and its influencing factors, and have drawn rich research conclusions. However, there is the lack of relevant research based on catering $\mathrm{O} 2 \mathrm{O}$ industry, integrating key elements such as delivery person's service and online after-sales service.

\subsection{Customer Experience and its Influencing Factors}

The rising and rapid development of $\mathrm{O} 2 \mathrm{O}$ industry in China has attracted extensive attention of researchers. Scholars conduct related researches on influencing factors of $\mathrm{O} 2 \mathrm{O}$ customer experience. From perspectives of $\mathrm{O} 2 \mathrm{O}$ platform, influencing factors include platform's ease of use, information content (Gao et al., 2015) [13], service response (Xu et al., 2015; Mao, 2018) [36, 57], interaction $(\mathrm{Yu}, 2015)$ [59], the process, culture and personality (Cui and Zhu, 2014) [11]; from perspectives of online and offline environment, online shopping environment, product category quality, offline shopping environment, employee service quality are influencing factors (Zhang and Zhao, 2014) [61]; from the perspective of the capability, influencing factors focus on the IT-enabled online and offline integration capability including prepurchase integration, purchase integration and postpurchase integration capability (Kong et al., 2017) [27].

The previous literature mainly focuses on $\mathrm{O} 2 \mathrm{O}$ platform, online and offline environment, and the key capability of $\mathrm{O} 2 \mathrm{O}$ firms, and explores influencing factors of $\mathrm{O} 2 \mathrm{O}$ customer experience. There are few researches focusing on encounter service quality, such as delivery service quality and after-sales service quality, and there are much fewer researches from catering O2O industry. Early scholars mostly use questionnaire, interview and other methods, most of which are qualitative analyses and make the results restrained by the respondents to a certain extent, with the lower reliability and the relatively weak timeliness of the data, and the lower efficiency of the survey. In view of this, this paper takes Meituan takeout as an example, based on the big data of customer reviews, and applies the grounded theory to analyse the text data of negative reviews deeply, so as to obtain influencing factors of catering $\mathrm{O} 2 \mathrm{O}$ customer experience.

\subsection{Catering 020 Customer Experience and its Influencing Factors}

During the past decade, catering customer experience has become a focal concept for scholars. The portion size and the quality of the food, the presence of other customers, the service quality of the staff, the restaurant atmosphere and location, as well as other social cues, are examples of the distinct characteristics that shape customer perceptions of the catering experience. Scholars have addressed catering experiences by measuring how customers perceive these different characteristics or attributes, often revolving around three constructs: the food, the quality, and the restaurant environment (Ryu et al., 2012, Heung and $\mathrm{Gu}, 2012)$ [21, 43]. First, food quality is the core element of customer experience. Customers conduct the experience through the perception of taste and nutritional value or through the aesthetics of food. The taste, variety and culture of catering food are the most important factors influencing customer experience. High quality food is the life of catering enterprises. Catering enterprises can use the particularity and differentiation expressed by food reasonably, and give customers unique consumption experience to win their own advantages. Quality is the key to maintain customer loyalty and to realize profits. Catering food quality contains three basic elements: hygiene, nutrition and sensory attributes. Catering industry is the industry with synchronization of production and consumption. Customers have higher and higher requirements for catering food now. If catering food quality cannot be guaranteed, it is bound to affect customers' perception of catering food and customer experience. Secondly, service quality is one of the main factors influencing customer experience. For example, the timeliness and initiative of the service will greatly affect customer experience of catering food. Service quality is an important factor for customers to choose catering food, and also the key to success of catering enterprises. Good service quality is helpful in attracting customers and bringing them good service experience, high customer satisfaction and customer loyalty. Third, the quality of the physical environment is also one of the main factors influencing customer experience. The physical environment includes identifying symbols, interior design, or other visual elements. High quality environmental experience brings good customer experience and customer satisfaction. Third, the quality of the physical environment is also one of the main factors influencing customer experience. The physical environment includes identifying symbols, interior design, or other visual elements. High quality environmental experience brings good customer experience and customer satisfaction.

In the context of the rapid development of mobile Internet and catering $\mathrm{O} 2 \mathrm{O}$, besides the food quality, customers focus more on the service quality of catering platforms and delivery enterprises. Customers communicate with enterprises through catering $\mathrm{O} 2 \mathrm{O}$ platform. As the third-party intermediary, catering $\mathrm{O} 2 \mathrm{O}$ platform is the bridge connecting customers and catering enterprises. The rapid development of mobile Internet brings about the customers focusing more on the interactivity, security and responsiveness of $\mathrm{O} 2 \mathrm{O}$ platform. Catering $\mathrm{O} 2 \mathrm{O}$ platforms provide online customer service, add pre-sale consultation and after-sale feedback service and transmit customer consumption experience and information to enterprises, so that enterprises can improve service quality according to changes in consumer demand, so as to improve service quality of takeout platforms and enhance customer stickiness. Catering O2O platforms conduct the satisfaction survey of after-sale return visit and irregular return visit survey of customers who have consumed, which cannot only make catering $\mathrm{O} 2 \mathrm{O}$ enterprises grasp consumption experience of customers timelier, but also help improve the service existing in catering $\mathrm{O} 2 \mathrm{O}$ platforms. In addition, catering $\mathrm{O} 2 \mathrm{O}$ platforms set up customer dispute handling unit, and the complaint module, handle customer complaints timely and effectively, and release processing results and customer 
feedback in a timely manner. These will affect catering O2O customer experience. Scholars' researches propose, when choosing catering $\mathrm{O} 2 \mathrm{O}$ platform, more and more customers pay attention to the feedback time and attitude of catering $\mathrm{O} 2 \mathrm{O}$ enterprises. The shorter the feedback time of catering enterprise on the platform is, the better the attitude is, the better customer experience is. In order to optimize customer experience for ordering takeout, catering $\mathrm{O} 2 \mathrm{O}$ platforms should enhance the management ability and improve the service response, optimize the service configuration, and strengthen the professional training of service persons (Gao et al., 2015) [13].

The last-mile delivery service is an important part of catering $\mathrm{O} 2 \mathrm{O}$ customer experience. In the process of food delivery, the delivery persons use simple delivery packages and boxes. Due to the longer delivery time, when the food arrives at the customer's, the food is cold, and there is even the leakage of the soup over other food. The appearance and taste of catering food are greatly reduced, which greatly affects customer experience. The accuracy and completeness of catering food delivery, the service attitude of delivery persons, the timeliness of catering food delivery and catering $\mathrm{O} 2 \mathrm{O}$ platform information update will affect catering $\mathrm{O} 2 \mathrm{O}$ customer experience. Catering $\mathrm{O} 2 \mathrm{O}$ platforms and enterprises manage and control the last-mile delivery service quality reasonably, which will make customers perceive the due service value and produce good customer experience and customer satisfaction. Customers will also be willing to purchase again, and recommend catering $\mathrm{O} 2 \mathrm{O}$ platforms and enterprises to the people around them. Scholars' researches point out that the service quality of catering $\mathrm{O} 2 \mathrm{O}$ platforms, catering $\mathrm{O} 2 \mathrm{O}$ enterprises and logistics delivery has an interactive impact on the development of catering O2O industry (Zhao, 2016) [62]. The delivery service quality, person service quality and personalized service quality of catering $\mathrm{O} 2 \mathrm{O}$ have a positive impact on customer perceived value and customer satisfaction (Wang, 2019) [54].

Based on the related researches of scholars mentioned above and the actual situation of catering $\mathrm{O} 2 \mathrm{O}$ in China, the paper puts forward the structure model of influencing factors of catering $\mathrm{O} 2 \mathrm{O}$ customer experience, as follows in Fig. 1.

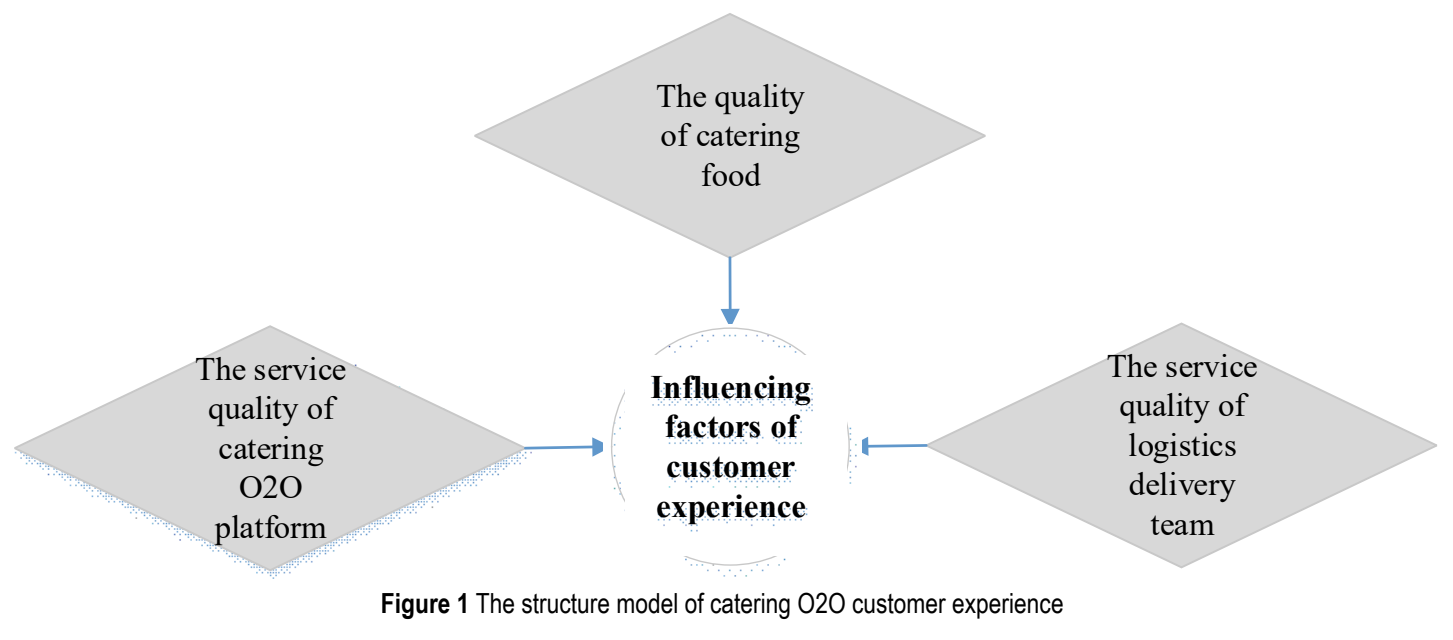

\section{RESEARCH METHOD}

Big data analysis plays an important role in making better decisions for business development. Big data analysis is an objective and scientific research method, and a process of deriving useful information by evaluating the real-world raw data. Quantitatively abundant and qualitatively authentic online customer reviews data are the precious source of information on catering $\mathrm{O} 2 \mathrm{O}$ customer experience. It is notably efficient to conduct big data analyses based on online customer reviews from perspectives of sample size and timeliness. Moreover, with the help of big data analysing tools, such as Octopus Web Data Collector and Python program, it is possible to identify and understand the core information in a piece of online customer review efficiently. Therefore, this article takes big data analysis as the meaning, and uses Octopus Web Data Collector to collect online customer data, and analyse the data with Python program. From the perspective of the research question, this article focuses on exploring the factors influencing customer experience. From the perspective of the research object, it is mainly aimed at customers of Meituan takeout platform, who will summarize their consumption experience into words and comment online.

\subsection{Data Collection}

Customer review text data in the paper is collected through Meituan takeout. In view of the immediacy, openness, and anonymity of the takeout platform, more authentic and free reviews can be found. The other reason for choosing Meituan takeout is that it is the takeout platform with the widest audience, highest reputation and highest degree of information richness in China at present.

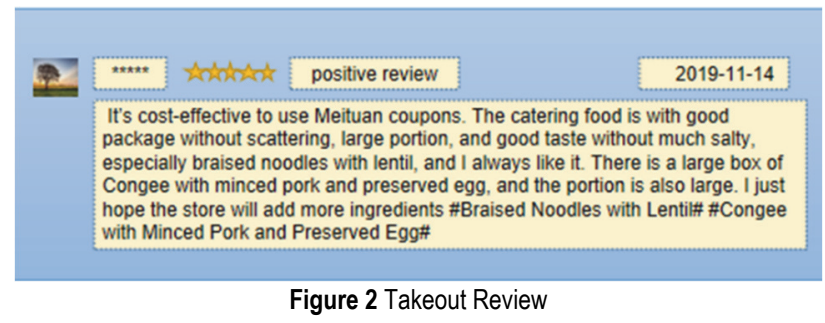

First, the data is collected through Octopus Web Data Collector, and a total of 54250 customer reviews from 
Meituan takeout platform are obtained. The information collected by Octopus is shown in Fig. 2. From this interface, the information of positive and negative reviews can be obtained directly, therefore, it is not necessary to make text sentiment analysis in the subsequent analysis of the data using Python.

\subsection{Data Processing and Analysis}

The expression of text reviews collected from Meituan takeout has great randomness, such as mixed use of Chinese and English punctuation, and adding various emoticons when expressing emotions. Such data have little effect. Therefore, in the whole process of text review mining they need to be processed. The specific steps are as follows:

First, natural language processing is conducted, that is, data preprocessing, to remove stop words. Jieba word segmentation package is used in Python language to segment words, using the exact mode. Exact mode can segment sentences most precisely and is suitable for text analysis.

Second, wordcloud is used to generate high-frequency words in overall customer reviews and word cloud diagram of high-frequency words in positive reviews from customers. The word cloud can highlight words with higher frequency in customer reviews visually, thereby filtering out a large amount of text information, so that people who read it can appreciate the main idea of the text.

Third, Matplotlib is used to generate word frequency bar graphs of the overall customer reviews. Matplotlib is a Python 2D drawing library, which can be used to draw many high-quality graphics.

\subsection{Data Analysis Results}

This article has conducted extensive research on catering $\mathrm{O} 2 \mathrm{O}$ customer reviews, and the results show that customer experience has a very complex structure. There are many factors influencing the shopping experience of takeout customers. The analysis results of this article are as follows:

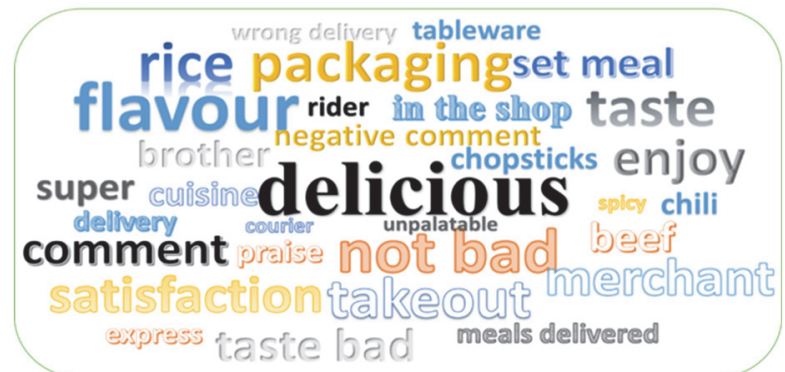

Figure 3 Word cloud diagram of high-frequency keywords in customer reviews

The high-frequency words extracted from the overall customer reviews through Python analysis are got, as shown in Fig. 3 and Fig. 4. The vocabulary related to food quality includes: "delicious", "taste", "unpalatable", etc. The proportion of these phrases is very high, which shows that customers pay great attention to food quality. Phrases, such as "rider", "courier", "brother", "wrong delivery" and "delivery" obviously describe the attributes related to the delivery process, which are the main factors to measure the delivery speed and service level of delivery staff. Phrases such as "packaging", "tableware", "wrong delivery", "chili", "spicy", "slightly spicy" also appear frequently.

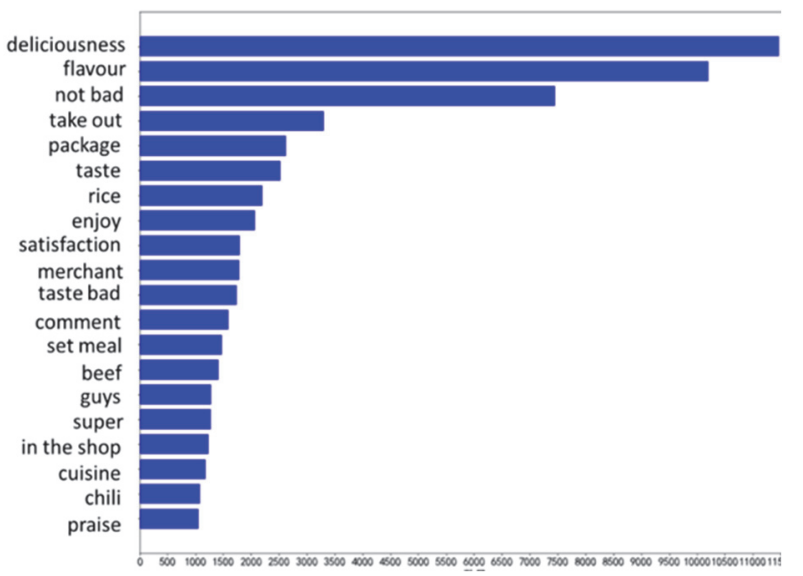

Figure 4 Bar graphs of high-frequency keywords in customer reviews

The results are obtained by analysing customer reviews using python, as shown in Fig. 5, which provide the visual effect for readers. It can be seen very intuitively from the figure that the proportion of words about "taste" is very high, such as "good taste", "great taste", "good dish", "delicious", which are used by customers to evaluate takeout quality, which plays an important role in influencing customer experience. In the figure, there are words related to serving size, such as "enough food", "sufficient quantity", and "large quantity". The proportion of these phrases is also very large, which shows food quantity also has a great impact on customer experience. There are also words, such as "high cost performance", "fair price", "working-hard courier brother" in the figure. It can be seen that takeout price and delivery staff will also influence customer experience.

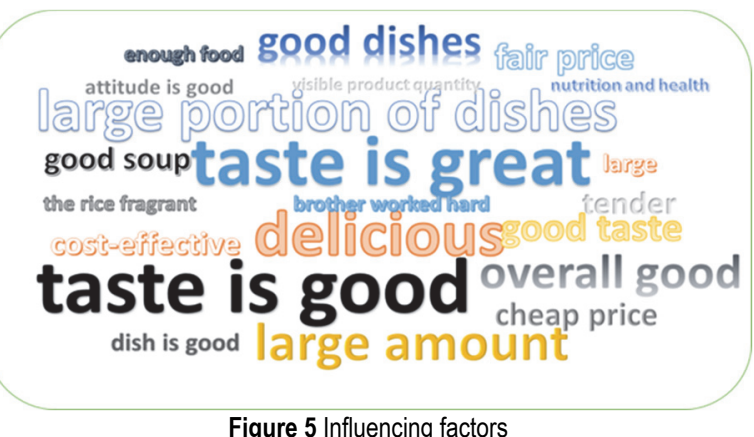

From the analysis results above, it can be seen that catering food quality, catering food quantity and delivery service quality will influence customer experience. The results are reflected in customer reviews to form electronic word-of-mouth, which will deeply influence customer satisfaction.

\subsection{Analysing Negative Reviews with the Grounded Theory}

The Grounded Theory is a method of building theory from the bottom top, which is based on the systematic collection of data and information, looking for suitable concepts that can reflect relevant phenomena, analysing and establishing the relationship between concepts, and 
finally forming the theory. This paper aims to explore which factors can promote catering $\mathrm{O} 2 \mathrm{O}$ customer experience. This paper believes that only from the practice, to find new phenomena and problems in catering $\mathrm{O} 2 \mathrm{O}$ customer experience through qualitative research methods, further extracts and refines the concepts and theoretical hypotheses needed in the study through the analysis and research of these phenomena and problems.

The reason why this paper chooses the Grounded Theory as the research method is that it is a scientific methodology. Its research idea is to collect a large number of data and information on specific issues, and constantly compare and speculate on the collected data and information, analyse and refine them, and finally obtain the concept and category in accordance with the problem situation from the data and information, and then construct the theoretical hypothesis on this basis.
The paper is mainly carried out through processes of open coding, axial coding and selective coding and it draws conclusions by comparing the relationship between the core category and other categories constantly, so as to guide the practice (Wang et al., 2015) [53]. This paper initially codes 600 negative reviews, and finally uses 200 negative reviews to test the theoretical saturation.

First of all, the negative reviews are coded openly. Open coding refers to the process of categorizing customer reviews one by one, using the categories to reflect the content of the data correctly, classifying, reorganizing, and summarizing. The purpose of open coding is to identify phenomena, define concepts, and find categories, that is, to deal with convergence problems. This process should be faithful to the data, to mine the category of the data. The open coding for customer reviews is shown in Tab. 1.

Table 1 Examples of Open Coding Analysis of Customer Reviews

\begin{tabular}{|c|c|c|}
\hline Problem statement & Conceptualization & Categorization \\
\hline $\begin{array}{l}\text { I am more and more disappointed at Dao Xiaoman, not to mention there is less amount of the soup } \\
\text { sent in reality than in the picture, and there's little beef, barely shredded bamboo shoots and corns. }\end{array}$ & $\begin{array}{l}\text { Less amount, lack of } \\
\text { materials }\end{array}$ & Portion \\
\hline $\begin{array}{c}\text { Why does the invoice not include the money of the packaging box? Although it's a takeout, I pay } \\
\text { for the packaging box. }\end{array}$ & $\begin{array}{l}\text { The problem with the } \\
\text { invoice }\end{array}$ & Invoice \\
\hline $\begin{array}{l}\text { I see this restaurant next to Mystic South-Yunnan Ethnic Cuisine. I am looking forward to it. But I } \\
\text { can't understand there is rotten vegetable leaves in the rice noodles for the newly ordered catering } \\
\text { food. }\end{array}$ & Unfresh & Freshness \\
\hline I buy so much food and the merchant just gives one set of dinnerware. What does it mean? & Less dinnerware & Dinnerware \\
\hline $\begin{array}{l}\text { The taste of takeout food is much worse than the one in the store, and the food delivered by the } \\
\text { delivery person is cold. }\end{array}$ & Worse taste, the cold food & $\begin{array}{l}\text { Taste, heat } \\
\text { preservation } \\
\text { performance }\end{array}$ \\
\hline $\begin{array}{l}\text { It used to be pretty good. This time, the rice noodles are sticky, and I don't know if they have gone } \\
\text { bad. }\end{array}$ & Unfresh & Freshness \\
\hline $\begin{array}{l}\text { The taste is very common. I have chosen this rice noodle shop, which is just a few hundred meters } \\
\text { away. But it is just warm. I haven't eaten up. }\end{array}$ & Worse taste, the cold food & $\begin{array}{l}\text { Taste, heat } \\
\text { preservation } \\
\text { performance }\end{array}$ \\
\hline I have written that the food should not be spicy, but it's still spicy. & Spicy & condiment \\
\hline $\begin{array}{l}\text { The food delivered is timely, but I can't understand that there is only } 7 \text { or } 8 \text { minutes away from the } \\
\text { merchant to the place where you deliver the food, and you needn't come out of the building. Why } \\
\text { is the soup warm and not hot, please explain that? }\end{array}$ & the cold food & $\begin{array}{l}\text { heat preservation } \\
\text { performance }\end{array}$ \\
\hline Should this kind of soup be not covered with plastic wrap? The soup has all spilt. & Soup spilt & package \\
\hline It is cold when it is delivered, and the rice noodles are all lumpy! & Cold, not fresh & $\begin{array}{l}\text { heat preservation } \\
\text { performance, freshness }\end{array}$ \\
\hline $\begin{array}{l}\text { There are no white rice noodles, roast chicken wings and pickled vegetables, and chopsticks, do } \\
\text { you want us to eat them by hand? The phone has been busy all the time, and I have never met the } \\
\text { takeout with an excessive attitude. }\end{array}$ & $\begin{array}{l}\text { Lack of materials, less } \\
\text { dinnerware, unable to } \\
\text { contact the merchant }\end{array}$ & $\begin{array}{l}\text { portion, dinnerware, } \\
\text { service attitude }\end{array}$ \\
\hline It's really dirty! & Poor hygiene & hygiene \\
\hline $\begin{array}{l}\text { It's too terrible. It shows it will be delivered at 9:50 when the order is placed, but it is delivered at } \\
10: 25 \text {. I'm too hungry to have the appetite to continue to eat. }\end{array}$ & The long time & Delivery speed \\
\hline $\begin{array}{l}\text { The food was not bad, it was delicious. The crayfish is really unpalatable. It is the most } \\
\text { unpalatable crayfish that I have ever eaten. There is also the hair of the fried seafood chef in the } \\
\text { crayfish. How terrible! }\end{array}$ & Poor taste, with hair & Taste, hygiene \\
\hline $\begin{array}{l}\text { I say two copies are packed separately. } \\
\text { Don't you read notes? }\end{array}$ & Do not read notes & Notes \\
\hline There is no salt in cooking the food. I can't eat it. & Too light & Condiment \\
\hline Confirm the signing for the food in advance, before it arrives. & Signing in advance & Order signing \\
\hline $\begin{array}{l}\text { The courier actually calls me to go downstairs to take the takeout back, saying that there are too } \\
\text { many orders, and there is no time to deliver to my home. It is really speechless. If I want to go } \\
\text { downstairs, I will not order the takeout, and I will eat in the store myself! }\end{array}$ & Poor courier service, & Delivery service \\
\hline $\begin{array}{l}\text { The delivery person is not familiar with the environment and the position and has phoned many } \\
\text { times. }\end{array}$ & Unproficiency in business & $\begin{array}{c}\text { Delivery person's } \\
\text { business ability }\end{array}$ \\
\hline What a rip-off! It's hard to eat and so expensive! I've thrown all away! & Poor taste, expensive & Taste, price \\
\hline $\begin{array}{l}\text { I ordered a working meal for my dad. We didn't have the meal together. After he finished eating, I } \\
\text { saw the garbage and found the wrong catering food delivered. I called and asked the catering } \\
\text { enterprise. After I explained the situation, the catering enterprise just said to the refund to the } \\
\text { payment account, and there was no apology. I'm going to eat, not to get a refund. I often order in } \\
\text { Meizhou Dongpo. I ordered sauteed tofu in hot and spicy sauce last night. Today, the beef I } \\
\text { ordered became tofu at noon. I am really dissatisfied. There's no service consciousness. It is really } \\
\text { more important for the attitude than everything in service industry. Please improve service } \\
\text { attitude. }\end{array}$ & $\begin{array}{l}\text { Wrong delivery, poor } \\
\text { attitude }\end{array}$ & $\begin{array}{l}\text { Food delivery } \\
\text { accuracy, service } \\
\text { attitude }\end{array}$ \\
\hline $\begin{array}{l}\text { There's a box of fried rice that hasn't been delivered, and there's also no person in catering } \\
\text { enterprise to answer the phone! }\end{array}$ & $\begin{array}{l}\text { Lack of material, unable to } \\
\text { contact the merchant }\end{array}$ & $\begin{array}{l}\text { The communication } \\
\text { between customers } \\
\text { and merchants }\end{array}$ \\
\hline
\end{tabular}


Second, axial coding is carried out on the result of open coding, and the categories obtained in the open coding are connected to establish the causal relationship between categories or concepts. By comparing and analysing the categories derived from the open coding, three main categories are obtained, namely catering food quality, delivery service quality and after-sales service quality. The final result of axial coding is shown in Tab. 2 .

Table 2 The Core Category Formed by Open Coding

\begin{tabular}{|c|c|c|}
\hline & Main category & Corresponding category \\
\hline 1 & Catering food quality & Taste, portion, freshness, heat preservation performance, condiment, hygiene, package, dinnerware, price \\
\hline 2 & Delivery service quality & $\begin{array}{c}\text { Delivery speed, delivery accuracy, order signing, delivery person's service quality, delivery person's } \\
\text { professional ability }\end{array}$ \\
\hline 3 & After-sales service quality & Invoice, the communication between customers and merchants, notes, service attitude \\
\hline
\end{tabular}

Third, selective coding is carried out. Selective coding refers to the process of constructing the theoretical model through rigorous analysis to select the core category and analyse the correlation path between the core category and other categories, based on the axial coding (Ren and Zhao, 2019) [40]. By analysing the relationship between the core category and other categories, this paper takes "influencing factors of catering $\mathrm{O} 2 \mathrm{O}$ customer experience" as the core category. Among them, the service quality of catering food is the basis for improving customer experience, the delivery service quality will directly affect the customer experience, and the after-sales service quality is the guarantee of customer experience. Based on the above analysis, this paper finally gets the model of the "catering food quality-delivery service quality-after-sales service quality". The results are shown in Fig. 6.

Taste, portion, freshness, heat preservation performance, condiment, hygiene, package, dinnerware, price

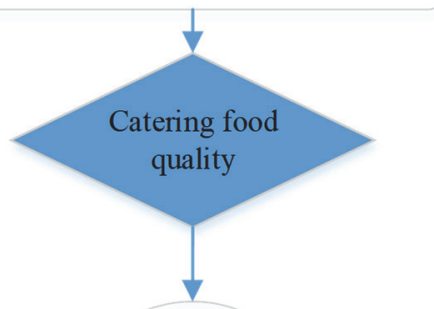

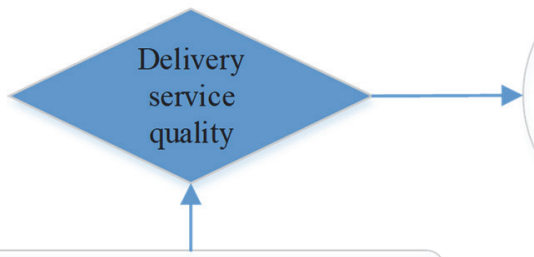

Delivery speed, delivery accuracy, order signing, delivery person $\check{\mathrm{s}}$ service quality, delivery person $\breve{s}$ professional ability
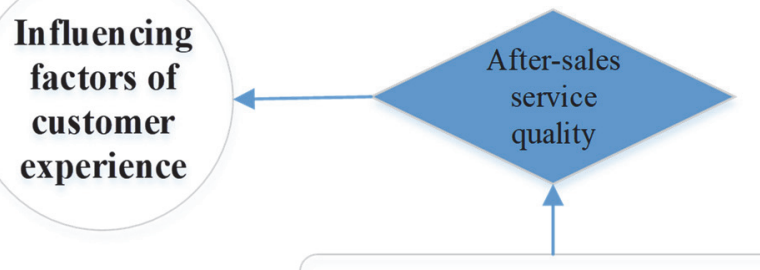

Invoice, communication between customers and merchants, notes, service attitude

Figure 6 Model of catering 020 customer experience

Finally, theoretical saturation test is conducted. Theoretical saturation test is the identification criteria that determine when to stop sampling (Li et al., 2018) [35]. When the customer's negative review is analysed and no new category is found, the analysis can be stopped. In order to conduct the theoretical saturation test, 200 customer negative reviews from a large sample are coded and analysed. The results show that the categories in the model have been developed sufficiently, and no new categories have been formed. It can be seen that the model of factors influencing the customer's negative review proposed in this paper is saturated theoretically.

Through the grounded theory, the paper verifies the structure model proposed, and determines influencing factors of catering $\mathrm{O} 2 \mathrm{O}$ customer experience, namely catering food quality, delivery service quality and aftersales service quality.

\subsection{Results and Discussion}

Through the analysis of customer reviews, this article concludes that catering food quality and delivery service quality will influence catering $\mathrm{O} 2 \mathrm{O}$ customer experience, and influence customer satisfaction further, whose final results are reflected in customer reviews.

Catering food quality is the key to catering $\mathbf{0 2 O}$ customer experience

Catering food quality is the primary factor influencing customer experience. The conclusion of this paper verifies that online catering experience is just like offline catering experience and for customers the key experience element of their concern is catering food quality. Through the data analysis above, it can be seen that catering food quality will influence customer experience. This is consistent with the research conclusions of many scholars. Now, food quality assurance has become an important part of the global food 
industry. Perceived catering food quality can be defined as the consumer's judgment of overall advantages and disadvantages of the product in meeting and/or exceeding customer expectations. Either the deficiency in product or service will lead to the poor customer experience. Perceived catering food quality is the important determinant of customer experience and satisfaction (Sun et al., 2016) [47].

The last-mile delivery service quality is the solid guarantee of catering $\mathrm{O} 2 \mathrm{O}$ customer experience

The research results of this paper find that delivery service quality will influence customer experience; they are consistent with Service Encounter Theory and the Moments of Truth Theory in the satisfaction model. Service encounter is "the moments of truth" in the process of the interaction between customer and service system, which is the direct source of influencing customer service perception [6]. Solomon believes that service encounter, namely, the interaction between customer and service delivery system, including frontline employees, customers, physical environment and other tangible factors, has the considerable impact on service differences, quality control, delivery system and other aspects, which will influence the evaluation of customers' perception of service quality. Moment of truth in the satisfaction model refers to each moment of the encounter with the customer, which starts from three aspects of the appearance, behaviour and communication of service staff. A large number of researches have shown that companies with higher service quality will deliver better customer experience, achieve higher customer satisfaction, increase customer retention rate, and generate financial performance. Last-mile delivery quality is often considered as an important decision criterion for online shoppers and last-mile delivery experience is one of the core elements of online shopping experience. Online shoppers attach great importance to fast and flexible delivery. Last-mile delivery quality has a significant impact on delivery experience, the whole online shopping experience and customer satisfaction (Vakulenko et al., 2019) [50]. In last-mile delivery service, the clean appearance, polite behaviour, timely and effective communication and efficient service of catering delivery staff can improve service quality at moment of truth and service encounter quality, and then improve customer experience and customer satisfaction.

\section{CONCLUSIONS AND IMPLICATIONS}

Catering $\mathrm{O} 2 \mathrm{O}$ is an important part of life services, which adapts to the development of the times. Previous scholars have studied factors influencing customer experience, but many of researches are not suitable for modern catering $\mathrm{O} 2 \mathrm{O}$. Therefore, this paper takes catering $\mathrm{O} 2 \mathrm{O}$ as the research background, analyses online reviews of catering $\mathrm{O} 2 \mathrm{O}$ customers, studies the factors influencing customer experience, and then constructs the model of catering $\mathrm{O} 2 \mathrm{O}$ customer experience. The results enrich the theory of catering $\mathrm{O} 2 \mathrm{O}$ customer experience and provide theoretical guidance for the healthy and efficient development of catering platforms and enterprises.

The analysis results of this paper show that among many factors influencing customer experience, catering food quality accounts for the largest proportion; catering portions, delivery efficiency and service quality all will affect customer experience. Therefore, both catering $\mathrm{O} 2 \mathrm{O}$ enterprises and catering $\mathrm{O} 2 \mathrm{O}$ platforms must keep a close eye on the contact points with customers, and improve customer experience in catering food, delivery and service, in order to increase customer satisfaction and promote the sustainable and rapid development of catering $\mathrm{O} 2 \mathrm{O}$ enterprises and catering $\mathrm{O} 2 \mathrm{O}$ platforms.

Catering 020 enterprises should ensure food quality to improve customer experience and customer satisfaction continuously

Catering $\mathrm{O} 2 \mathrm{O}$ enterprise is the core of ensuring customer experience and catering food quality, portion, and package provided by the enterprise are important factors influencing customer experience and customer satisfaction. In the digital age, although various new technologies provide the convenience for enterprise development, with the online platform becoming more stable and the technical means becoming more homogenized, the core element of catering enterprise competition is still the catering food quality. Therefore, catering $\mathrm{O} 2 \mathrm{O}$ enterprises should provide customers with good experience from the aspects of catering food quality, portion, and package. First of all, catering $\mathrm{O} 2 \mathrm{O}$ enterprises should ensure catering food quality, implement total quality management, and ensure the safety and freshness of food materials; establish food traceability system so that the logistics information of food materials can be inquired, and the responsibility can be investigated, so as to protect the interests of customers effectively; meanwhile, catering $\mathrm{O} 2 \mathrm{O}$ enterprises should pay close attention to the customer's notes on takeout orders, which reflect customers' special requirements for catering food to a large extent, and respond to customer needs accurately and efficiently, to maintain the good customer experience. Secondly, catering $\mathrm{O} 2 \mathrm{O}$ enterprises should ensure the consistency of the portion of take-out food and dine-in food, or remind customers of the differences in portions before placing an order, and even inform customers of the specific portion size clearly, so as to ensure that customers will not have wrong expectations. Finally, catering o2o enterprises should use different types of product packages, especially the food with soup, according to their own actual situation, pay attention to sealing, and at the same time, ensure the freshness of the food in the package, so as to ensure catering food quality and improve customer experience.

Catering 020 platforms should improve delivery service and after-sale service continuously, to win better customer experience and electronic word-ofmouth

Last-mile service experience is one of the core elements of catering $\mathrm{O} 2 \mathrm{O}$ customer experience, which affects customer experience and customer satisfaction directly. Catering O2O platform should improve delivery service quality in distribution link and perfect supervision and feedback mechanism to ensure customer experience. First, delivery speed and service quality of delivery person are the key points in distribution link. Catering $\mathrm{O} 2 \mathrm{O}$ platform should attach great importance on the service of contact points in distribution link to ensure customer experience and customer satisfaction in distribution link. Delivery persons should receive professional and 
systematic training before taking up their posts to improve service quality. In addition, catering $\mathrm{O} 2 \mathrm{O}$ platforms can introduce the real-time congestion information of urban roads in the distribution plan to improve delivery efficiency, so as to improve customer experience and customer satisfaction effectively (Yao and He, 2019) [58]. In order to ensure the freshness of catering food, the platforms should provide professional delivery equipment for delivery persons, improve customer experience of delivery service, obtain positive reviews and win electronic word-of-mouth. Second, the platforms should establish the sound supervision and feedback mechanism to ensure customer experience of service contact points. As the thirdparty platform, catering $\mathrm{O} 2 \mathrm{O}$ platforms should establish the comprehensive enterprise supervision mechanism, and review catering $\mathrm{O} 2 \mathrm{O}$ enterprises applying for admission strictly and comprehensively, so as to ensure enterprise qualification. At the same time, catering $\mathrm{O} 2 \mathrm{O}$ platforms should establish the efficient online service feedback mechanism to safeguard the core interests of customers and provide good customer experience of service contact points.

\section{Limitations and future research}

The data sources in this paper are quite extensive, but there is the lack of pertinence to a certain extent. There are many categories of catering enterprises, and different categories have different effects on customer experience. Therefore, the paper needs to explore influencing factors of catering $\mathrm{O} 2 \mathrm{O}$ customer experience by category, and constantly enrich the input variables in the model of catering $\mathrm{O} 2 \mathrm{O}$ customer experience. In addition, on the basis of the existing research, the paper can make an empirical study on the relationship between customer experience and e-word-of-mouth, verify the relationship between the two variables, and further verify the results of this paper.

\section{Acknowledgments}

The paper is supported by Beijing Social Science Fund (17GLC050), Premium Funding Project for Academic Human Resources Development in Beijing Union University (BPHR2020CS05), Key Projects of Scientific Research Plan of Beijing Municipal Education Commission (SZ202111417021), the Academic Research Projects of Beijing Union University (JS10202006) and Teaching Innovation Course Construction Project in Beijing Union University (12205561107-132).

\section{REFERENCES}

[1] Aaltojarvi, I., Kontukoski, M., \& Hopia, A. (2018). Framing the local food experience: A case study of a Finnish pop-up restaurant. British Food Journal, 120(1), 133-145. https://doi.org/10.1108/BFJ-12-2016-0613

[2] Andaleeb, S. S. \& Conway, C. (2006). Customer satisfaction in the restaurant industry: an examination of the transactionspecific model. Journal of Services Marketing, 20(1), 3-11. https://doi.org/10.1108/08876040610646536

[3] Andersson, T. D. \& Mossberg, L. (2004). The dining experience: do restaurants satisfy customer needs? Food Service Technology, 4(4), 171-177. https://doi.org/10.1111/j.1471-5740.2004.00105.x
[4] Barrett, M., Davidson, B., Prabhu, J., \& Vargo, S. L. (2015). Service innovation in the digital age: Key contributions and future directions. MIS Quarterly, 39(1), 135-154. https://doi.org/10.25300/MISQ/2015/39:1.03

[5] Becker, L. \& Jaakkola, E. (2020). Customer experience: fundamental premises and implications for research. Journal of the Academy of Marketing Science, 19, 1-19. https://doi.org/10.1007/s11747-019-00718-x

[6] Bitner, M. J. (1990). Evaluating service encounters: the effects of physical surroundings and employee responses. Journal of Marketing, 54, 69-82. https://doi.org/10.1177/002224299005400206

[7] Bolton, R. N., Gustafsson, A., McColl-Kennedy, J., Sirianni, N., \& Tse, D. K. (2014). Small details that make a big difference: a radical approach to consumption experience as a firm's differentiating strategy. Journal of Service Management, 25(2), 253-274. https://doi.org/10.1108/JOSM-01-2014-0034

[8] Bolton, R. N., McColl-Kennedy, J. R., Cheung, L., Gallan, A., Orsingher, C., Witell, L., \& Zaki, M. (2018). Customer experience challenges: Bringing together digital, physical and social realms. Journal of Service Management, 29(5), 776-808. https://doi.org/10.1108/JOSM-04-2018-0113

[9] Brocato, E. D., Voorhees, C. M., \& Baker, J. (2012). Understanding the influence of cues from other customers in the service experience: a scale development and validation. Journal of Retailing, 88(3), 384-398. https://doi.org/10.1016/j.jretai.2012.01.006

[10] Ciuchita, R., Mahrb, D., \& Odekerken-Schröderc, G. (2019). "Deal with it": How coping with e-service innovation affects the customer experience. Journal of Business Research, 103,130-141. https://doi.org/10.1016/j.jbusres.2019.05.036

[11] Cui, J. \& Zhu, X. D. (2014). The Exploration of Factors Influencing Consumption Experience Based On the 020 Model. Journal of Modern Information, 34(12), 55-59+63.

[12] Escobar-Rodríguez, T., Grávalos-Gastaminza, M. A., \& Pérez-Calañas, C. (2017). Facebook and the intention of purchasing tourism products: Moderating effects of gender, age and marital status. Scandinavian Journal of Hospitality and Tourism, 17(2), 129-144. https://doi.org/10.1080/15022250.2015.1137784

[13] Gao, H., Yang, B. W., \& Wang, J. (2015). Research on the Influence Factors of Repeat Consumption Intention in 020 Takeaway Business Mode. Commercial Research, 6, 126132.

[14] Garms, M., Fredman, P., \& Mose, I. (2017). Travel motives of German tourists in the Scandinavian mountains: The case of Fulufjället National Park. Scandinavian Journal of Hospitality and Tourism, 17(3), 239-258. https://doi.org/10.1080/15022250.2016.1176598

[15] Gilboa, S., Seger-Guttmann, T., \& Mimran, O. (2019). The unique role of relationship marketing in small businesses' customer experience. Journal of Retailing and Consumer Services, 51, 152-164. https://doi.org/10.1016/j.jretconser.2019.06.004

[16] González-Rodríguez, M. R., Martinez-Torres, R., \& Toral, S. L. (2016). Post-visit and pre-visit tourist destination image through eWOM sentiment analysis and perceived helpfulness. International Journal of Contemporary Hospitality Management, 28(11), 2609-2627. https://doi.org/10.1108/IJCHM-02-2015-0057

[17] Grace, D. \& O'Cass, A. (2004). Examining service experiences and postconsumption evaluations. Journal of Services Marketing, 6, 450-461. https://doi.org/10.1108/08876040410557230

[18] Grewal, D., Levy, M., \& Kumar, V. (2009). Customer experience management in retailing: an organizing framework. Journal of Retailing, 85(1), 1-14. https://doi.org/10.1016/j.jretai.2009.01.001 
[19] Grove, S. J. \& Fisk, R. P. (1992). The service experience as a theatre. Advances in Consumer Research, 19, 455-461.

[20] Harrington, R. J., Ottenbacher, M. C., Staggs, A., \& Powell, F. A. (2012). Generation Y consumers key restaurant attributes affecting positive and negative experiences. The Journal of Hospitality \& Tourism Research, 36(4), 431-449. https://doi.org/10.1177/1096348011400744

[21] Heung, V. C. \& Gu, T. (2012). Influence of restaurant atmospherics on patron satisfaction and behavioral intentions. International Journal of Hospitality Management, 31(4), 1167-1177. https://doi.org/10.1016/j.ijhm.2012.02.004

[22] Hoffman, D. L. \& Novak, T. P. (2017). Consumer and object experience in the Internet of Things: An assemblage theory approach. Journal of Consumer Research, 44(6), 1178-1204. https://doi.org/10.1093/jcr/ucx105

[23] Homburg, C., Jozié, D., \& Kuehnl, C. (2015). Customer experience management: toward implementing an evolving marketing concept. Journal of the Academy of Marketing Science, 45(3), 377-401. https://doi.org/10.1007/s11747-015-0460-7

[24] Izogo, E. E. \& Jayawardhena, C. (2018). Online shopping experience in an emerging e-retailing market. Journal of Research in Interactive Marketing. https://doi.org/10.1108/JRIM-02-2017-0015

[25] Klaus, P. (2013). The case of amazon.com: towards a conceptual framework of online customer service experience (OCSE) using the emerging consensus technique (ECT). Journal of Services Marketing, 27(6), 443-457. https://doi.org/10.1108/JSM-02-2012-0030

[26] Klaus, P. P. \& Maklan, S. (2013). Towards a better measure of customer experience. International Journal of Market Research, 55(2), 227-246. https://doi.org/10.2501//JMR-2013-021

[27] Kong, D., Sun, K., \& Zhang, M. X. (2017). How to use online and offline integration to improve customer experience, China Business and Market, 31(6), 45-52.

[28] Kranzbühler, A., Kleijnen, M. H. P., Morgan, R. E., \& Teerling, M. (2018). The multilevel nature of customer experience research: an integrative review and research agenda. International Journal of Management Reviews, 20, 433-456. https://doi.org/10.1111/ijmr.12140

[29] Kuehnl, C., Jozic, D., \& Homburg, C. (2019). Effective customer journey design: consumers' conception, measurement, and consequences. Journal of the Academy of Marketing Science, 47(3), 551-568. https://doi.org/10.1007/s11747-018-00625-7

[30] Kumar, V., Umashankar, N., Kim, K. H., \& Bhagwat, Y. (2014). Assessing the influence of economic and customer experience factors on service purchase behaviors. Marketing Science, 33(5), 673-692. https://doi.org/10.1287/mksc.2014.0862

[31] Kwok, L., Xie, K., \& Richards, T. (2017). Thematic framework of online review research: A systematic analysis of contemporary literature on seven major hospitality and tourism journals. International Journal of Contemporary Hospitality Management, 29(1), 307-354. https://doi.org/10.1108/JJCHM-11-2015-0664

[32] Larivière, B., Bowen, D., Andreassen, T. W., Kunz, W., Sirianni, N. J., Voss, C., \& Keyser, A. (2017). "Service Encounter 2.0": An investigation into the roles of technology, employees and customers. Journal of Business Research, 79, 238-246. https://doi.org/10.1016/j.jbusres.2017.03.008

[33] Lemke, F., Clark, M., \& Wilson, H. (2011). Customer experience quality: an exploration in business and consumer contexts using repertory grid technique. Journal of the Academy of Marketing Science, 39(6), 846-869. https://doi.org/10.1007/s11747-010-0219-0
[34] Lemon, K. N. \& Verhoef, P. C. (2016). Understanding customer experience throughout the customer journey. Journal of Marketing, 80, 69-96. https://doi.org/10.1509/jm.15.0420

[35] Li, Y., Wang, K., \& Li, D. J. (2018). Models of influencing factors of merchants' behaviors endangering food safetyBased on the rooted research of online forum reviews. Economics and Management Research, 39(8), 95-107.

[36] Mao, Y. Q. (2018). Research on the influence of customer experience and offline presence of merchants on Acceptance Intention of community $\mathrm{O} 2 \mathrm{O}$ E-commerce. Economic \& Trade, 2, 217.

[37] Meyer, C. \& Schwager, A. (2007). Understanding customer experience. Harvard Business Review, February, 1-12.

[38] Nieto-García, M., Muñoz-Gallego, P. A., \& GonzálezBenito, Ó. (2017). Tourists' willingness to pay for an accommodation: The effect of eWOM and internal reference price. International Journal of Hospitality Management, 62, 67-77. https://doi.org/10.1016/j.ijhm.2016.12.006

[39] Novak, T. P., Hoffman, D. L., \& Yiu-Fai, Y. (2000). Measuring the customer experience in online environments: a structural modelling approach. Marketing Science, 19(1), 22-42. https://doi.org/10.1287/mksc.19.1.22.15184

[40] Ren, Q. L. \& Zhao, Z. Y. (2019). Research on factors affecting the quality of online ride-hailing service based on grounded theory. Journal of Chongqing Jiaotong University, 38(2), 94-101.

[41] Rose, S., Clark, M., Samouel, P., \& Hair, N. (2012). Online customer experience in e-retailing: an empirical model of antecedents and outcomes. Journal of Retailing, 88, 308322. https://doi.org/10.1016/j.jretai.2012.03.001

[42] Ryu, K., Jang, S., (2008). DINESCAPE: a scale for customers' perception of dining environments. Journal of Foodservice Business Research, 11(1), 2-22. https://doi.org/10.1080/15378020801926551

[43] Ryu, K., Lee, H., \& Kim, W. G. (2012). The influence of the quality of the physical environment, food, and service on restaurant image, customer perceived value, customer satisfaction, and behavioral intentions. International Journal of Contemporary Hospitality Management, 24(2/3), 200223. https://doi.org/10.1108/09596111211206141

[44] Singh, R. \& Söderlund, M. (2019). Extending the experience construct: an examination of online grocery shopping. European Journal of Marketing, 6, 309-336.

[45] Siqueira, J. R., Peñab, N. G., Horstc, E., \& Molinad, G. (2019). Spreading the Word: How Customer Experience in a Traditional Retail Setting Influences Consumer Traditional and Electronic Word-of-mouth Intention. Electronic Commerce Research and Applications, 37, 1-11. https://doi.org/10.1016/j.elerap.2019.100870

[46] Stein, A. \& Ramaseshan, B. (2020). The customer experience - loyalty link: moderating role of motivation orientation. Journal of Service Management, 31(1), 51-78. https://doi.org/10.1108/JOSM-04-2019-0113

[47] Sun, H. Y., Ni, W. B., \& Wang, Z. Q. (2016). A consumption system model integrating quality, satisfaction and behavioral intentions in online shopping. Information Technology and Management, 17(2). https://doi.org/10.1007/s10799-015-0254-0

[48] Teixeira, J., Patrício, L., Nunes, N. J., Nóbrega, L., Fisk, R. P., \& Constantine, L. (2012). Customer experience modeling: from customer experience to service design. Journal of Service Management, 23(3), 362-376. https://doi.org/10.1108/09564231211248453

[49] Trevinal, A. M. \& Stenger, T. (2014). Toward a conceptualization of the online shopping experience. Journal of Retailing and Consumer Services, 21(3), 314-26. https://doi.org/10.1016/j.jretconser.2014.02.009

[50] Vakulenko, Y., Shams, P., Hellström D., \& Hjort, K. (2019). Online retail experience and customer satisfaction: the mediating role of last mile delivery. The International 
Review of Retail, Distribution and Consumer Research, 29(3), 306-320. https://doi.org/10.1080/09593969.2019.1598466

[51] Verhoef, P. C., Lemon, K. N., Parasuraman, A., Roggeveen, A., Tsiros, M., \& Schlesinger, L. A. (2009). Customer experience creation: determinants, dynamics and management strategies. Journal of Retailing, 85(1), 31-41. https://doi.org/10.1016/j.jretai.2008.11.001

[52] Voorhees, C. M., Fombelle, P. W., Gregoire, Y., Bone, S., Gustafsson, A., Sousa, R., \& Walkowiak, T. (2017). Service encounters, experiences and the customer journey: Defining the field and a call to expand our lens. Journal of Business Research, 79, 269-280. https://doi.org/10.1016/j.jbusres.2017.04.014

[53] Wang, C. Z., Gao, Q., \& Gebauer, H. (2015). Research on cross-border logistics collaborative system of service spare parts based on grounded theory. Management Review, 27 (2), $178-186+208$.

[54] Wang, D. (2019). An Empirical Study on the Influencing Factors of Customer Satisfaction of Catering Takeaway 020 Logistics Service Quality. Logistics Technology, 45-48.

[55] Wellton, L., Jonsson, I. M., Walter, U., \& Svingstedt, A. (2017). Restaurant practices: Time, planning, knowledge and dreams. Scandinavian Journal of Hospitality and Tourism, 17(3), 297-311. https://doi.org/10.1080/15022250.2016.1176951

[56] Xu, J. B. \& Chan, A. (2010). A conceptual framework of hotel experience and customer-based brand equity: some research questions and implications. International Journal of Contemporary Hospitality Management, 22(2). https://doi.org/10.1108/09596111011018179

[57] Xu, L. H., Xiang, J. C., Yin, H., \& Huang, Z. Z. (2015). Research on the relationship between experience value and customer satisfaction of online booking in $\mathrm{O} 2 \mathrm{O}$ mode. Consumer Economics, 31(05), 46-50.

[58] Yao, Y. G. \& He, S. Y. (2019). Research on agricultural products cold chain logistics distribution path optimization based on traffic big data. Management Review, 31(4), 240253.

[59] Yu, B. H., Yang, Y. Q., Sun, J. L., Qin, J. \& Xu, Y. (2015). The Effects of Customer Offline Experience and Merchant Offline Presence on Customer Acceptance of Community 020 Ecommerce. Chinese Journal of Management, 12(11), 1658-1664.

[60] Yrjölä, M., Rintamäkia, T., Saarijärvia, H., Joensuua, J., \& Kulkarnib, G. (2019). A customer value perspective to service experiences in restaurants. Journal of Retailing and Consumer Services, 51, 91-101. https://doi.org/10.1016/j.jretconser.2019.05.030

[61] Zhang, Q. \& Zhao, L. (2014). Research on the Influence Factors of Repeat Consumption Intention in O2O Takeaway Business Mode. Science and Technology Management Research, 34(12), 200-204.

[62] Zhao, L. \& Lu, S. (2016). Structural equation modelling of key factors influencing the development of catering 020 . Finance and accounting monthly, 15, 88-92.

\section{Contact information:}

Chunyang SHI, Postgraduate

Institution: Management College, Beijing Union University,

Postal address: 97 North Fourth Ring East Road, 100101, China

E-mail:18810255850@163.com

Yilei PEI, Associate Professor

(Corresponding author)

Institution: Management College, Beijing Union University,

Postal address: 97 North Fourth Ring East Road, 100101, China

E-mail: peiyilei@126.com

Dandan LI, Associate Professor

Institution: Management College, Beijing Union University,

Postal address: 97 North Fourth Ring East Road, 100101, China

Ting WU, Postgraduate

Institution: Management College, Beijing Union University,

Postal address: 97 North Fourth Ring East Road, 100101, China 